Indonesian Journal of Islamic Communication, Vol. 2, No. 1, Juli 2019: 1-21

\title{
POLA KOMUNIKASI PERSPEKTIF TALCOTT PARSONS DALAM MEMBINA HARMONI KERUKUNAN UMAT BERAGAMA PADA MASYARAKAT DESA KEBANGSAAN WONOREJO SITUBONDO
}

\author{
Adi Susianto \\ Program Studi Komunikasi dan Penyiaran Islam \\ Institut Agama Islam Negeri Jember
}

Diunggah 02 Juni / Direvisi 21 Juni / Diterima 28 Juli 2019

\begin{abstract}
Abstrac: Wonorejo has many differences between religions, but the language still has a high tolerance. Religious diversity breeds a plurality of national social life that is close to brotherhood, tolerance and togetherness. In the context of religious rituals, the village people freely implement religious teachings in accordance with their respective beliefs without injuring and disturbing other faiths and religions. This is the success of real effective communication in the Wonorejo village, Situbondo districts.
\end{abstract}

Keywords; Communication, Religious Harmony, Wonorejo Village

Korespondensi: Adi Susianto

Pascasarjana IAI Jember 


\section{A. PENDAHULUAN}

Kekerasan atas nama agama di berbagai negara khususnya di Indonesia telah terjadi sejak dulu, akan tetapi meningkat dengan tajam terjadi pasca reformasi politik 1998 bersamaan dengan menguatnya gerakan Islam garis keras (radikal). ${ }^{1}$ Hal ini terlihat pada dua dekade terakhir di wilayah yang memiliki peta rawan konflik tinggi, seiring terbukanya saluran politik identitas ke partai politik ataupun tata kelola pemerintahan. Paling tidak ada tiga konflik yang menjadi masa catataan kelam dalam sejarah yang menumpahkan banyak korban, membuktikan bahwa bangsa Indonesia belum dapat mengelola perbedaan dan keragaman berbagai identitas itu. Terjadinya konflik di Ambon-Maluku yaitu konflik agama (Islam-Kristen) , konflik agama (Islam-Kristen) yang juga terjadi di Poso, dan konflik suku Dayak dan Madura di Kalimantan, merupakan tiga peristiwa konflik yang berskala besar dan memakan korban ribuan jiwa .2

Ini menjadi tragedy yang sangat mengerikan di waktu itu. Belum lagi konflik lain yang menghiasi Indonesia seperti yang terjadi di Sampang Madura, Cikeusik Banten, peperangan antardesa dan ulayat di Papua dan Nusa Tenggara, serta menyusul tragedi lain di berbagai daerah dengan pola dan sebab yang berbeda.

Banyak faktor kerusuhan yang bersifat SARA (Suku, Agama, dan Ras) itu bisa juga terjadi karena mengarah pada persoalan kesalahpahaman, penguasaan sumber daya, dan persoalan Pemilukada di suatu daerah. ${ }^{3}$ Perkelahian atau amuk massa antarkampung di Nusa Tenggara dan Sulawesi seperti kejadian Palopo 2013, bukan semata dipahami sebagai perselisihan sekelompokpemudatentang asmara, sebagaimana juga misalnya asumsi-asumsi yang diajukan pada kasus penyebab konflik Sampang Madura, atau pertentangan sekelompok massa tentang batas-batas tanah. Konflik yang bermula pada persoalan yang juga dapat diartikan sebagai suatu runtutan akumulatif dari proses-proses yang disebabkan oleh persoalan kompleks, termasuk di dalamnya persoalan SARA dan lebih lebih kepentingan politik identitas yang mengatasnamakan itu.

\footnotetext{
1 Ahmad Zainul Hamdi, "Klaim Religious Authority dalam Konflik Sunni-Syi'i Sampang Madura", ISLAMICA, Vol. 6, No. 2 (Maret 2012), 217

2 Syamsuddin Haris, Masalah-masalah Demokrasi dan Kebangsaan Era Reformasi. (Jakarta: Pustaka Obor. 2014), 92-93

3 Ibid., 24-28
} 
Upaya upaya mendamaikan konflik yang dilakuakan untuk meredam perpecahan. Salah satunya adalah perdamaian Malino sebagai ikhtiar penyelesaian konflik Poso, namun ini dapat diprediksi masih ada konflik lain yang akan terjadi yang senada dengan hal tersebut. Perkiraan terhadap wilayah konflik baru didasarkan pada indikasi-indikasi dari tingkat kerawanan sosial di daerah yang luar biasa tinggi, sebagai akibat dari kegagalan pendidikan harmoni, provokasi atas nama politik identitas (untuk kepentingan Pemilukada), kesenjangan ekonomi antara penduduk lokal dengan warga pendatang, transmigrasi, dan wilayah tradisional yang didasarkan pada etnik dan agama, dan proses interaksi dan akulturasi dua atau lebih dari karakter kebudayaan masing- masing etnik yang tidak berhasil atau mengalami kegagalan dalam suatu irama kehidupan bersama.

Dalam peristiwa-peristiwa yang terjadi diatas, sebab musabab terjadinya peristiwa tersebut sebenarnya tidak terlepas dari pola-pola tertentu sebagai manifestasi prilaku manusia dalam berkomunikasi. Ditinjau dari pola yang dilakukan ada beberapa jenis yang dikomunikasikan. Beberapa sarjana Amerika membagi pola komunikasi menjadi lima, yakni komunikasi antarpribadi, komunikasi kelompok kecil, komunikasi massa dan komunikasi publik. Istilah pola komunikasi biasa disebut sebagai model, yaitu sistem yang terdiri atas berbagai komponen yang berhubungan satu sama lainnya untuk mendapatkan tujuan secara bersama, Joseph A. Devito membagi pola komunikasi menjadi empat yakni komunikasi antarpribadi, komunikasi kelompok kecil, komunikasi publik, dan komunikasi massa. ${ }^{4}$

Akan tetapi disisi lain, negeri ini selalu terbuka terhadap pemikiran pemikiran dari luar dan telah terbukti ramah terhadap budaya luar. Kondisi tersebut menjadikan Indonesia sebagai negera yang memiliki keanekaragaman dalam berbagai sektor baik dari segi bahasa, adat, suku, kondisi alam, maupun agama. Dengan demikian, Indonesia memiliki kompleksitas yang tinggi dengan jumlah agama yang dimiliki di antaranya Islam, Katolik, Protestan, Hindu, dan Budha. Dalam komponen agama tersebut, Islam merupakan agama yang dianut oleh mayoritas penduduk di Indonesia. Banyaknya agama yang dianut oleh bangsa Indonesia, menimbulkan sejumlah dilematika yang berhubungan dengan penganut antar agama. ${ }^{5}$

\footnotetext{
${ }^{4}$ Nurudin, Sistem Komunikasi Indonesia ( Jakarta, PT Grafindo Persada : 2007), 26-28

5 Mawardi, "Reaktualisasi Kerukunan Antar Umat Beragama", Substantia, 17 (April 2015), 55
} 
Awalnya, problematika antar agama ini muncul pada aspek penyebaran agama. Setiap agama, terutama Islam dan Kristen sangat mementingkan masalah penyebaran agama. Karena masing-masing pemeluk merasa memiliki kewajiban untuk menyebarkannya, masing-masing yakin bahwa agamanyalah satu-satunya kebenaran yang menyangkut keselamatan di dunia dan di akhirat. ${ }^{6}$

Gambaran Kemajemukan di atas terjadi pada masyarakat Desa Wonorejo Kecamatan Banyuputih Kabupaten Situbondo. Wonorejo yang dikenal dengan Desa kebangsaan, memiliki jumlah penduduk sebanyak enam ribu orang lebih. Agama yang dianutnya terdiri dari Islam, protestan, Budha dan hindu. Tempat ibadah yang tersedia terdiri dari : Masjid sebanyak enam tempat, Gereja satu tempat,Wihara satu tempat, dan Pure satu tempat.

Namun di desa Wonorejo yang memiliki banyak perbedaan antar agama, bahasa tetap memiliki tolenransi yang tinggi. keanekaragaman agama melahirkan pluralitas kehidupan sosial kebangsaan yang erat dengan persaudaraan. Toleransi,dan kebersamaan. Dalam konteks ritual keagamaan, masyarakat desa kebangsaan dengan bebas melaksanakan ajaran agama sesuai dengan keyakinan masing masing tanpa mencederai dan mengganggu keyakinan dan agama yang lain. Berdasar penuturan Khoirul Anwar ${ }^{4}$ masyarakat bukan hanya memberikan kebebasan untuk menjalankan ritual agama, melainkan memberikan pelayanan keamanan bagi masing masing pemeluk agama. Ketika umat Islam menjalankan ibadah sholat Jum'at, dan hari besar Islam, umat budha, protestan,dan hindu ikut menjaga keamanan di luar masjid. Bahkan pada saat malam takbiran, umat yang beragama lain ikut memeriahkan dengan juga berkeliling kampung dengan membantu memainkan bedhuk dan alat lainnya tanpa harus ikut bertakbir. Sebagai bentuk keakraban dan kebersamaan salah satu pendeta menjadi pelatih aransemen pada salah satu kelompok musik Islam (hadrah).

Begitu juga ketika umat budha, protestan, dan hindu menjalankan ibadah maka, umat Islam ikut bertanggung jawab menjaga kelancaran dan kemananan baik dari pra pelaksanaan hingga pasca pelaksanaan. Kebersamaan ini yang membuat desa wonorejo (desa kebangsaan) menjadi desa yang kompak dan meriah dalam

\footnotetext{
${ }^{6}$ Syamsul Hadi, "Abdurrahman Wahid: Pemikir tentang Kerukunan Umat Beragama", (Tesis, Universitas Muhammadiyah, Surakarta, 2015), 2

${ }^{4}$ Khoirul Anwar, wawancara, Banyu Putih Situbondo, 17 Agustus 2017
} 
menjalankan ritualitas keagamaan. Salah satu ritualitas yang menjadi media kebersamaan yaitu ritual malam jum'at manis yang berisi permohonan dan perenungan spiritual.

Ritualitas tersebut dilakukan di tempat yang diyakini memiliki kekuatan supranatural yang oleh masyarakat disebut candiwang. Bentuk ritual yang digunakan sesuai dengan agama yang di yakininya. Umat Islam melaksanakannya dengan istigotsah, tahlilan, dan sholawatan. Mereka meyakini bahwa candiwang merupakan petilasan (tempat bertapa) seorang kekasih Allah yang bisa dijadikan sarana bertabarruk. Umat protestan, budha dan hindu melakukan ritual tersebut dengan bersemedi sesuai ajaran agamanya. Mereka juga meyakini bahwa candiwang merupakan sarana untuk menuju dan meraih kasih Tuhan.

Selain kebersamaan dan keharmonisan dalam beragama, kehidupan sosial kebangsaan masyarakat juga integrative dan harmonis. Selama kurang lebih dua puluh tahun berlangsung desa Wonorejo tercatat oleh pemerintah daerah sebagai desa yang mempertahankan dan menjunjung tinggi nilai kebangsaan dan Negara Republik Indonesia. Setiap tanggal 17 Agustus, masyarakat memperingati hari kemerdekaan dengan pelbagai kegiatan kebangsaan yang diantaranya upacara pagi harinya dan dilanjutkan dengan drama kolosal yang menampilkan sosok dan Jasa para pahlawan dalam merebut dan mempertahankan kemerdekaan republik Indonesia.

Dalam hal ini, Talcott Parsons dengan teori Fungsionalisme Strukturalnya menawarkan empat imperative yaitu Adapsi, Pencapaian Tujuan (Goal Attainment), Integrasi (Integration), dan Latensi (Latency) untuk melihat sebuah peristiwa konflik Agama \& SARA atas dasar keberagaman .

\section{B. PEMBAHASAN}

\section{Pola Tindakan Komunikatif Dialog Antar Agama}

Pada hakikatnya komunikasi diandaikan dengan interaksi minimal dua orang. Dalam hakikat komunikasi tersebut menurut, tindakan komunikatif terarah pada "saling pengertian" (verstandigung) dan "koordinasi hidup bersama", di mana setiap orang melaksanakan kebebasannya dengan mengakui dan menerima orang lain sebagai subyek yang bebas. Tindakan komunikatif seperti ini berada 


\section{Adi Susianto}

dalam situasi tindakan yang bersifat sosial sehingga tindakannya strategis, bukan tindakan yang instrumental dan berada dalam situasi yang bersifat non sosial. ${ }^{7}$

Teori tindakan komunikasi Habermas ini dapat dipahami dan dijelaskan secara skematis, yang tampak berikut ini: Skema 1: Tindakan Komunikasi

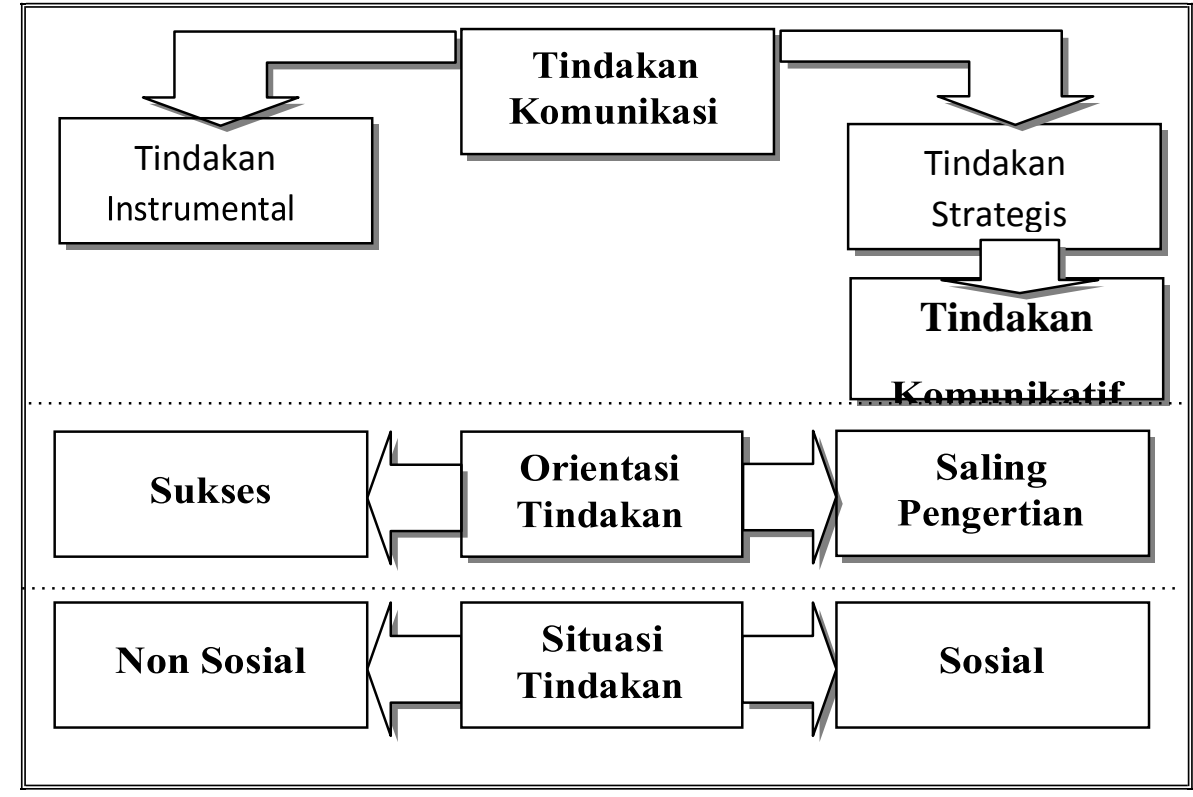

Pada aktifitas dialog antar umat beragama, komunikasi sesungguhnya juga merupakan suatu bentuk komunikasi dari "pengalaman iman". Jika iman dipahami sebagai dasar tindakan komunikatif. Ini berarti bahwa hanya pada pengalaman imanlah tindakan komunikatif dalam konteks dialog antar umat beragama sungguh menjadi mungkin, karena pengalaman iman yang sejati merupakan puncak kepenuhan hidup pribadi manusia. Sebagaimana diungkapkan oleh Joao Piedade Inocencio bahwa:

"Hanya pada pengalaman imanlah, setiap orang tanpa diskriminasi diakui dan diterima penuh sebagai subyek bebas. Atas dasar itulah, setiap orang dapat terlibat pada kepentingan sesamanya dalam sebuah solidaritas universal."8

Di satu pihak, perubahan masyarakat memang ditentukan oleh basis-basis material ekonomi, politik dan sosial. Di lain pihak, teori kritis mengajukan peran kesadaran manusia yang mampu mengubah sebuah transformasi sosial jika proses komunikasi dilakukan oleh pelaku-pelaku sadar diri secara terbuka dan terus-menerus dengan memertahankan dialog-dialog memertemukan

\footnotetext{
${ }^{7}$ Jürgen Habermas, The Theory of Communicative Action, vol. I, trans. Thomas McCarthy (Boston: Beacon Press, 1985), 285.

${ }^{8}$ Joao Piedade Inocencio, SJ., "Proses Dialog Interaksi” dalam Budi Susanto, Teologi dan Praksis Komunikasi Post-modern (Yogyakarta: Kanisius, 1994), 124.
} 
kepentingan-kepentingan pribadi dengan komunikasi aktif untuk mengambil konsensus-konsensus titik-titik temu kepentingan bersama.

Budaya konsensus bukan tidak mungkin bisa dicapai. Seseorang hanya mengacu kepada pernyataan masyarakat-budaya yang telah dipertanyakan, dan konsensus ini hanya dapat ditetapkan oleh prosedur diskursif dan argumentasi yang menerima suatu jarak pasti dari konteks praktis. ${ }^{9}$ Budaya konsensus dapat terjadi, mengingat Habermas menyinggung tentang terdapatnya juga kesamaan antara struktur identitas ego dan identitas group. Ego epistemik, sebagaimana ego pada umumnya, dikarakteristikkan oleh struktur umum kognitif, bahasa dan kemampuan aktif yang juga terjadi pada setiap ego individu, sebagaimana di dalam perwujudan tindakan-tindakannya. Hal ini menjamin identitas person di dalam struktur epistemik dari ego pada umumnya, serta memertahankan kesinggungan sejarah kehidupan dan ikatan simbolik diri sistem pribadi melalui identifikasi aktualitas diri yang berulang-ulang. Dan, dikenali di dalam relasi intersubyektif dari dunia kehidupan sosialnya. ${ }^{10}$

Kemungkinan terjadinya distorsi dalam komunikasi, dan tidak tercapainya komunikasi yang saling pengertian, adalah terdapatnya pribadi-pribadi neurotik di antara partisipan komunikasi. Habermas menjelaskan individu yang tidak mengerti tindakannya sendiri, tidak berumber dari kesadarannya sendiri, dan cenderung melakukan rasionalisasi. Individu neurotik tidak mengerti tindakannya sendiri, tindakannya itu yang berasal dan motif-motif yang terhalau dari kesadarannya. Ia diasingkan oleh bagian dirinya dari dirinya sendiri, maka kehadirannya terwujud dalam bentuk rasionalisasi. Rasionalisasi menyembunyikan kebenaran darinya, karena kelakuannya. Rasionalisasi dapat dikritik dan dilihat. Untuk mengatasi individu-individu yang neurotik atau yang cenderung ber-rasionalisasi itu, Habermas menyinggung tentang refleksi dan kritik diri. Dalam hal ini psikoanalisis amat membantu.

"Psikoanalisis membantu pasien untuk melengkapi tugas ini, di mana ia dapat kembali lagi kepada kekuatan rasionalnya dan sadar atas tindakantindakannya". 11

\footnotetext{
${ }^{9}$ Kortian, Metacritique, 124-125.

10 Jürgen Habermas, Communication and the Evolution of Society, 106.

11 Julius Sensat, Habermas and Marxism (London: Sage Publication, 1979), 28-29.
} 
Sedangkan, refleksi diri merupakan sebuah proses di mana tekanantekanan yang semu alamiah dilenyapkan secara kritis. kegiatan ini sangat posistif sebagai sebuah proses pencerahan, pencapaian kemandirian dan tanggung jawab. Ketergantungan teori kritis pada proses ini berkaitan dengan pencapaian emasipasi.

“Di dalam refleksi diri pencarian pengetahuan mencapai keserupaan dengan keinginan dalam otonomi dan tanggung jawab... Dalam kekuatan refleksi diri, pengetahuan dan keinginan adalah satu".12

Habermas mengkonkretkan konsep refleksi diri yang sifatnya emansipatoris itu atau kritik dalam paradigma komunikasi dengan memerlihatkan cara kerja psikoanalisis Sigmund Freud sebagai "hermeneutika dalam". Maksud Habermas adalah :

"Melalui kritik penyembuhan ini, distorsi-distorsi ideologis yang membuat para anggota masyarakat terhambat perkembangannya mencapai otonomi dan kedewasaan ingin dihancurkan. Psikoanalisis dipandang sebagai metode yang mampu membawa ketidaksadaran ke permukaan kesadaran. Habermas mengingatkan metode ini jangan dipandang lepas dari konteks, melainkan harus diletakkan dalam praksis komunikasi”.42

Sehubungan dengan pengaruh kritik Marxis, Habermas menjelaskan bagaimana ia memahami kekuatan emasipatoris dari kritik dalam hubungannya dengan metodologi maupun kondisi sejarah. Metode kritik berdiri di antara ilmu pengetahuan dan filsafat. Dan, juga bahwa kritik berkaitan dengan kesadaran akan krisis sosial dan kondisi historis tertentu.

Menurutnya, krisis terjadi ketika konsensus masyarakat terganggu, sehingga terjadi kontradiksi dalam klaim-klaim kesahihan. Di abad ke-19, teori Karl Max dengan tajam menjelaskan krisis itu bersama penyelesaiannya. Dalam wawasan penyingkapan krisis dan pencapaian tahap konsensus sosial yang baru, teori krisis memainkan peranannya untuk mendorong masyarakat menuju masyarakat yang komunikatif.

Menuju masyarakat komunikatif inilah dialog agama bisa dicapai, meskipun agama satu dengan lainnya adalah berbeda. karena, di dalam perbedaan 
itu sekaligus terdapat persamaannya. Atas dasar arti perbedaan dan persamaan inilah, dialog antar umat beragama merupakan pertemuan hati dan pikiran antara multi-agama. Dialog merupakan komunikasi antara dua atau lebih orang yang beragam. Dialog ini jalan bersama menuju ke arah kebenaran, partnership tanpa ikatan dan tanpa maksud yang tersembunyi. Menurut Mukti Ali (1994), dialog bukan hanya saling memberi informasi mengenai agama yang dipeluk, baik persamaan maupun perbedaan satu agama dengan lainnya, dialog antar agama juga tidak sama dengan usaha dari orang untuk menjadikan dirinya yakin akan agama yang ia peluk, dan menjadikan orang lain memeluk agama yang ia peluk.

Sebab itu, dalam dialog orang tidak perlu, bahkan tidak boleh meninggalkan agama dan kepercayaannya. Bahkan sebaliknya, agamanya sendiri dipegang teguh disertai sikap penghargaan kepada agama dan kepercayaan orang lain. Dialog antar umat beragama sedapatnya berhasil menuntut kepada pesertanya sikap mental, seperti menghargai orang lain, mau mendengarkan pendapat orang lain, jujur, terbuka, dan bersedia untuk bekerjasama dengan orang lain. Sikap mental seperti ini terdapat pada para peserta dialog yang telah memiliki kesadaran moral otonom dan menganut nilai-nilai universal.

Bagi umat beragama, dalam dialog antar agama akan terasa terjaminnya serta dihormatinya iman dan indentitasnya pihak lain, serta terbukanya peluang untuk membuktikan keagungan agamanya. Dialog antar agama yang didasarkan pada tindakan komunikatif ini diarahkan untuk mencapai pemahaman dan pengertian timbal-balik, tanpa adanya dominasi dari suatu pihak kepada pihak lainnya. Karena itu, meski mayoritas Islam masyarakat kota Cilegon harus memerankan tindakan komunikatif.

Francis Cardinal Arinze mengungkapkan bahwa:

"Dialogue is not an academic debate, which each side trying to prove that it has the truth an that the other is in error. It is the comparative study of religious, nor the placing of beliefs and practices of one alongside those of another religion as one might place two exhibits, on a museum shelf, inter religious dialogue is not a tea party with all making small talk and avoiding any issues which might be uncomfortable or conflictual. Dialogue is nine of these things. What we mean by dialogue, rather, is meeting other believers in opener, in a willingness to listen, to understand, to walk together and to work together. It is the willingness to open oneself to God a section in us, which can also come through contact with others. Since the term "dialogue" too often carries implications of simply talking or discussing, it might since these speak about inter religious relations, might speak of inter religious harmony, include in the concept of the dialogue are relations at the level of daily life, 


\section{Adi Susianto}

discussion and study session among scholars, cooperation in social projects, and the exchange of religious experience". ${ }^{13}$

Berdasarkan keterlibatan peneliti dalam pengamatan dengan organisasi keislaman (ranting NU) dengan umat Kristen (GKI Wonorejo) dalam aktifitas sehari-hari maupun formal, dialog antar umat agama Islam , Kristen dan Budha di desa Wonrejo memiliki empat pola, berikut ini: pertama; pola Tindakan Komunikatif.

Tindakan komunikatif (communicative action), seperti diungkapkan Habermas, tidak dapat dilepaskan dengan rasionalitas yang mendasarinya. Maka, dalam tindakan komunikatif Habermas menarik sebuah rasionalitas yang disebut rasionalitas komunikatif. Rasionalitas komunikatif ini berbeda dari rasionalitas instrumental. Tindakan komunikatif ini sungguh-sungguh rasional dan dapat dipertanggungjawabkan.

"Sebuah tindakan sungguh manjadi rasional, dalam arti tidak "ngawur", tidak semena-mena jika bisa dipertanggungjawabkan lewat jalan argumentasi atau forum diskusi".

Tindakan komunikatif mengarah pada saling pengertian (verstandingung) antara pembicara dan pendegar. Dalam tindakan bahasa, misalnya. Ucapan yang ditujukan kepada seseorang tidak hanya bersifat memerintah untuk mencapai suatu tujuan, melainkan mengambil bagian dalam proses komunikasi. Maksudnya, kalau dua orang berbicara, tindakan bicara itu berorientasi kepada saling pengertian atau kesepakatan mengenai kondisi-kondisi yang mengatur atau mengkoordinir tindakan-tindakan mereka supaya hidup bersama menjadi mungkin.

Jenis tindakan berkaitan dengan orientasinya untuk mencapai tujuan tertentu, atau untuk mencapai saling pengertian. Dalam orientasi mencapai tujuan, tindakan tersebut bersifat instrumental bila untuk situasi tindakan yang bukan bersifat sosial, sedangkan menyangkut situasi tindakan yang bersifat sosial, maka tindakan tersebut bersifat strategis. Tindakan komunikatif berada dalam situasi tindakan yang bersifat sosial.

13 Fransisco Budi Hardiman, Menuju Masyarakat Komunikatif (Yogyakarta: Kanisius, 1993), xxxiii. . XXV. 
Dialog antar agama sebagai suatu bentuk tindakan komunikasi, bisa dimasukkan ke dalam tindakan komunikatif yang berdasarkan rasionalitas komunikatif. Dengan demikian, dialog antar agama sebagai sebuah proses pengertian memperhitungkan situasi dan kondisi, seperti partner pembicara dengan klaim kebenaran agama yang diyakininya.

"Berhasil tidaknya koordinasi itu tergantung dari apakah partner bicara saya menerima atau menolak validitas pernyataan saya. Bahasa pada hakikatnya terarah pada saling pengertian antar manusia". Hanya dalam pola tindakan komunikatif bahasa diandaikan sebagai sebagai "medium lengkap saling pengertian (verstandigung) di mana pembicara dan pendengar, dari cakrawala dunia kehidupan mereka yang ditafsirkan, berhubungan dengan sesuatu yang sekaligus ada dalam dunia obyektif, sosial dan subyektif, untuk merundingkan rumus-rumus situasi bersama. ${ }^{14}$

Tindakan komunikatif selalu merupakan suatu tindakan berbicara dan karenanya mengadaikan "medium bahasa di mana hubungan-hubungan pelaku dengan dunia tercermin sebagaimana adanya. Pengungkapan penghayatan iman dari masing-masing peserta yang terjadi dalam dialog antar agama, juga merupakan tindakan komunikatif yang mempergunakan bahasa. Karenanya, refleksi iman yang dikomunikasikan itu hanya terlaksana dalam tindakan berbicara menggunakan bahasa dengan memperhitungkan situasinya.

Tindakan komunikatif mengandaikan partisipasi pihak-pihak yang terlibat dalam interaksi. Karenanya, pelaku-pelaku dalam dialog antar agama sungguhsungguh lebih dari sekadar sebagai pengamat. Dalam dialog antar agama, tindakan komunikatif dengan berdasarkan rasionalitas komunikatif amat diperlukan karena dalam tindakan komunikasi inilah tuntutan kesaling- mengertian timbal balik itu dimungkinkan.

Habermas mengatakan bahwa medium bahasa tentu diandaikan dan digunakan juga oleh tiga pola tindakan lainnya yang dihasilkan oleh teori ilmuilmu sosial: pola teleologis, pola normatif, dan pola dramaturgis. Setiap pola mengimplikaikan hubungan tertentu dengan dunia.

${ }^{14}$ Joao Piedade Inocencio, SJ., "Proses Dialog Interaksi” dalam Budi Susanto, Teologi dan Praksis Komunikasi Post-modern, 108 
Ketiga pola tindakan: dramaturgis, normatif dan teleologis memiliki hubungan yang berat sebelah dengan bahasa. Dan, setiap model hanya mencakup satu jenis hubungan dengan dunia.

"Pola telelologis menganggap bahasa sebagai satu alat di anatara berbagai alat lainnya untuk mencapai tujuan subyek dengan membuat orang lain memberikan opini yang sesuai dengan kepentingan pelaku sendiri. Pola normatif memandang bahasa sebagai sarana penyalur norma-norma. Dan, pola dramaturgis memperlakukan bahasa sebagai medium ekspresi diri”.

Pola tindakan teleologis merupakan tindakan yang ditentukan oleh suatu tujuan, dan bahasa merupakan hanya sarana. Dalam dialog antar agama berdasarkan pola ini akan memerlihatkan partisipasi menjadikan dialog hanya sebagai sarana untuk tujuan tertentu, memengaruhi keyakinan partner dialog, dan bukan dalam rangka mencapai saling pengertian timbal balik.

"Pola tindakan teleologis menyangkut tindakan subyek yang ditentukan oleh suatu tujuan untuk dicapai. Subyek berhubungan dengan obyek dalam rangka menguasainya secara teoritis maupun praktis. Di sini bahasa termasuk salah satu dari pelbagai sarana yang dipakai. Untuk memengaruhi partnernya membentuk opini atau maksud yang sesuai dengan kepentingan mereka”.

Pola tindakan normatif menunjuk pada norma-norma. Subyek memainkan perannya dalam interaksi dengan orang lain dengan bertindak sesuai dengan norma. Tindakan subyek di sini tidak diatur oleh sebuah tujuan yang ingin dicapai, melainkan oleh norma yang perlu dihormati, norma-norma yang diakui dalam sebuah kelompok sosial.

Dalam dialog antar agama terdapat norma-norma dari masing-masing agama yang dihormati, maupun norma yang disepakati bersama, atau nilai-nilai yang sifatnya universal. Begitu pun, terhadap norma agamanya sendiri, bagi peserta dialog berlaku klaim kesesuaian. Jadi, pola tindakan normatif, juga harus diperhatikan dalam dialog antar agama.

"Gambaran dunia yang dapat ditarik dari model ini ialah bahwa dunia bukan hanya dunia obyektif sebagaimana terimplikasi dalam model teleologis, melainkan dimensi sosial yang diatur oleh norma-norma. Pola ini mengandaikan bahasa sebagai medium yang menyampaikan nilai-nilai budaya dan memberikan dasar konsensus bersama". 
Pola tindakan dramaturgis pertama-tama tidak mencakup seorang pelaku terisolir, maupun anggota sebuah kelompok sosial tetapi para peserta sebuah interkasi di mana setiap seorang melihat orang lain sebagai publiknya dan dihadapannya ia menampilkan diri. Pelaku menimbulkan dalam publiknya gambaran dirinya sendiri dengan menguak diri, membuka kemungkinan bagi publik untuk memasuki lingkup pemikiran, suasan hati, kejujuran serta perasaannya yang paling pribadi. Ia ingin diterima seturut kesan yang ia cetak dalam publik.

"Gambaran dunia yang diandaikan pola ini adalah sebuh image dirinya pada publik, pelaku mau tidak mau berhubungan dengan dunia subyektifnya sendiri bahwa ia sendirilah yang punya akses paling optimal terhadap dirinya sendiri. Pola ini mengandaikan bahasa sebagai sarana menampilkan diri di depan publik, sebuah alat untuk ekspresi diri. Bahasa disetarafkan dengan bentukbentuk ekspresi gaya bicara dan estetis".

Pola tindakan dramaturgis dinyatakan oleh Habermas mengandung prinsip menghadirkan diri, atau proyeksi dari citra publik. Konsep tindakan dramaturgis ini pada pokoknya diinspirasikan dari Erving Goffman yang menggunakan permainan peran (role games) dalam teater untuk menerangi perjumpaan sosial. Istilah permainan peran di sini mengacu kepada tindakan yang berasal secara sosial dibandingkan pada tindakan yang bebas.

"Setiap tindakan dramaturgis adalah strategis secara implisit, bermaksud menimbulkan respon dari para pendengarnya. Di dalam teater kehidupan, hal itu diasumsikan sebagai suatu kondisi kepercayaan timbal balik di mana perananperanan yang dimainkan para aktor serupa dengan karakter mereka yang sebenarnya".

Untuk dialog antar agama, pola tindakan dramaturgis dengan klaim keotentikan, menyarankan bahwa setiap penampilan partisipan dialog hendaknya jujur sesuai dengan klaim kebenaran yang menjadi keyakinannya. Sikap dramaturgis ini hendaknya tidak menjadikan peserta dialog berakting yang hanya menampilkan konformitas atau sikap kompromi, kepura-puraan yang semu.

Interaksi yang terjadi atas dasar tindakan komunikatif tidaklah bebas nilai, melainkan memiliki basis nilai. Artinya, dengan mengatakan sesuatu bisa 


\section{Adi Susianto}

sekaligus menyatakan atau mengangkat sebuah pretensi akan validitas (Geltungsanpriche) kita. Kita berpretensi bahwa yang kita katakan itu sah. Habermas mengungkapkan tentang tiga pretensi validitas: kebenaran, kesesuaian, dan keotentikan. Masing-masing berkaitan dengan dunia obyektif, normatif, dan subyektif. Validitas itu tercermin dalam model tindakan telelologis, normatif, dan dramaturgis.

Dalam teori tindakan komunikasinya, Habermas menyebutkan empat macam klaim.

1. Klaim kebenaran (truth) jika sepakat mengenai dunia alamiah dan obyektif.

2. Klaim kesesuain (rightness) jika sepakat mengenai pelaksanaan norma-norma dalam dunia sosial.

3. Klaim otentisitas atau kejujuran (sincerity) jika sepakat mengenai kesesuaian antara dunia batiniah dan ekspresi individu.

4. Klaim komprehensibilitas (comprehensibility) jika kita bisa menjelaskan

macam-macam klaim itu dan mencapai kesepakatan atasnya.

Habermas membedakan antara proses belajar yang refleksif. Yang pertama, mengambil di dalam konteks tindakan yang secara implisit timbul klaim validitas baik yang teoritis maupun praktis dan yang sudah semestinya diterima atau ditolak secara sederhana tanpa penjelasan diskursif. Yang kedua, mengambil tempat ketika klaim-klaim validitas itu dievaluasi secara diskursif. Karena perbincangan adalah metode yang layak untuk mengevaluasi klaim- klaim itu, maka pembelajaran yang refleksif menyajikan suatu perkembangan yang mengatasi pembelajaran yang bukan refleksif.

Pembelajaran yang refleksif akhirnya memungkinkan terjadinya revolusi ilmu pengetahuan, mengingat revolusi ilmu pengetahuan adalah suatu perkembangan besar dari kekuatan-kekuatan produktif, yakni suatu lingkungan pengetahuan yang dapat digunakan secara teknis "diangkat ke dalam proses pembelajaran yang refleksif".

Universalitas klaim-klaim validitas yang inhern di dalam struktur pembicaraan mungkin dapat diterangkan dengan kerangka sistematik bahasa. 
Bahasa adalah sarana di mana pembicara dan pendengar menyatakan garis batas fundamental yang pasti. Garis batas subyek pada dirinya sendiri yang terdiri dari. (1) Suatu lingkungan yang diobyektivasikan di dalam sikap orang ketiga dari suatu pengamat. (2) Suatu lingkungan yang dikonfrontasikan kepada atau penyimpangan dalam sikap diri orang lain dari seorang peserta. (3) Subyektivitas dirinya sendiri yang ia wujudkan atau sembunyikan di dalam sikap orang pertama. (4) Sarana bahasa pada dirinya sendiri untuk menguasai realitas itu. 56 Tindakan komunikasi pada akhirnya tidak terlepas dari pembicaraan, dan subyek pembicara. Situasi pembicara tersebut juga melahirkan persyaratan tertentu yang dibutuhkan pembicara.

Ketika seseorang harus bertindak secara komunikatif di dalam penampilan sebuah tindakan pembicaraan, maka ia menumbuhkan klaim-klaim validitas universal dan menginginkan partisipasi di dalam sebuah proses untuk mencapai pengertian. Sebagai pembicara ia juga menuntut :

(a) Sesuatu pernyataan yang dapat dimengerti

(b) Memberikan (pendengar) sesuatu untuk mengerti

(c) Membuat dirinya dapat dimengerti, dan

(d) Siap untuk mengerti dengan orang lain.

Tindakan komunikatif atau kompetensi komunikasif dalam sebuah tindakan pembicaraan itu lewat tiga tahap komunikasi. (1) Tingkat interaksi yang diperantarai secara simbolik. (2) Tingkat pembicaraan yang dibedakan secara proposisi. (3) Tingkatan pembicara yang argumentatif.57 Pada tingkat interaksi yang diperantarai secara sombolik, pembicaraan dan tindakan masih dalam kerangka tunggal dalam mode komunikasi yang imperatif. Pada tingkat pembicaraan yang dibedakan secara proposisi, untuk pertama kalinya tindakan dan pembicaraan dipisahkan. A dan B dapat menghubungkan sikap-sikap penampilan dengan sikap proposisional dari sebuah pengamat, masing-masing tidak hanya menerima perspektif yang lain, tetapi dapat saling menukar perspektif, entah sebagai pelalu atau pengamat.

Pada tingkat ketiga, pembicara yang argumentatif, klaim kesahihan yang kita kaitkan dengan pembicaraan dapat menjadi tematik yang luar biasa. Tiga 
tahap kompetensi komunikatif tersebut bisa untuk melihat apa yang terdapat pada pelaku dialog antar agama. Pada tahap pertama, para peserta berada dalam tataran kenyataan yang sama, berupaya saling memenuhi harapan. Selanjutnya, pada tahap kedua, tataran tindakan dan tuturan terpisah, peserta dapat berperan baik sebagai pelaku maupun pengamat, mengungkapkan aspirasinya atau sebagai pengamat yang tidak terlibat untuk mencapai pemahaman obyektif. Dan, pada tahap ketiga pernyataan-pernyataan mereka secara hipotesis diuji, misalnya dengan prinsip-prinisip universal.

\section{Talcott Parsons Memandang Harmoni Kerukunan Beragama Desa Kebangsaan Wonorejo Kabupaten Situbondo}

Gambaran Harmoni kerukunan desa Kebangsaan Wonorejo kabupaten Situbondo. Dengan tampilan beberapa kegiatan dan tempat tempat yang terawat sejak dulu sebagai simbol kerukunan. Diataranya Tumpeng Sewu, ruwetan, candywang dan lain lain.

Semua itu merupakan fakta sosial sebagaimana George Ritzer membagi fakta sosial menjadi dua yaitu material dan non material. Material adalah segala sesuatu yang dapat dirasakan panca indra. Sedangkan Non Material adalah sesuatu kejadian yang dianggap nyata dan terjadi hanya dalam keadaan sadar. ${ }^{15}$

Pada Fungsionalisme struktur itu dianggap sesuatu yang nyata atau fakta sosial non material. Karena dalam fungsionalisme struktur menyebutkan bahwa dalam masyarakat terdapat struktur. Itupun terjadi pada desa kebangsaan Wonorejo kabupaten Situbondo. Hal ini ditandai dengan struktur kelembagaan desa, sejak berdirinya desa Wonorejo sampai kepala desa sekarang Sumarto Adi. Tentunya dengan tugas, fungsi dan pokok masing masing yang tidak terlihat oleh mata, namun dapat dirasakan.

Adapun Talcott Parsons dalam Fungsionalisme Struktur, bias kita mengkaji sebagaimana berikut :

1. Masyarakat dipandang sebagai bagian daripada system yang tidak terpisahkan. Dalam kata lain bagian yang bias dipisahkan.

15 George Ritzer, Sosiologi Ilmu Pengetahuan Berparadigma Ganda (Jakarta: Raja Grafindo Persada), 21. 
2. Antara bagian satu dengan bagaian yang lainnya saling berhubungan. Hal ini disebut dengan hubungan timbal balik.

3. Integrasi sosial tidak bersifat statis, sehingga tidak pernah menggapai kesempurnaan karena selalu selalu bersifat dinamis, cenderung mengarah kepada keseimbangan.

4. Apabila terjadi ketidak fungsian salah satu bagian, penyimpangan dan ketegangan, maka dengan sendirinya akan terselesaikan melalui penyesuaian (adaptasi) dan berjalannya proses pelembagaan dengan rentan waktu yang panjang.

5. Dengan adaptasi pula, maka perubahan secara bertaham pada sistem sosial.

6. Tiga kemungkinan terjadinya perubahan sosial diantaranya : Pertumbuhan dengan proses difresiasi dan fungsional, adaptasi dengan perubahan dari pihak eksternal.

7. Faktor penting dalam integrasi sistem sosial yaitu consensus dan kesepakatan. ${ }^{16}$

Deskripsi diatas menandakan setiap sistem memiliki fungsi. Talcott Parsons menyatakan ada empat fungsi sebagaimana berikut :

1. Adaptation (adaptasi)

Akan tetapi disisi lain, negeri ini selalu terbuka terhadap pemikiran pemikiran dari luar dan telah terbukti ramah terhadap budaya luar. Kondisi tersebut menjadikan Indonesia sebagai negera yang memiliki keanekaragaman dalam berbagai sektor baik dari segi bahasa, adat, suku, kondisi alam, maupun agama. Dengan demikian, Indonesia memiliki kompleksitas yang tinggi dengan jumlah agama yang dimiliki di antaranya Islam, Katolik, Protestan, Hindu, dan Budha. Dalam komponen agama tersebut, Islam merupakan agama yang dianut oleh mayoritas penduduk di Indonesia. Banyaknya agama yang dianut oleh bangsa

16 Nasikun, Sistem Sosial Indonesia (Yogyakarta: Raja Grafindo Persada), 10-11. 
Indonesia, menimbulkan sejumlah dilematika yang berhubungan dengan penganut antar agama. ${ }^{17}$

Hal ini tergambar dalam situasi masyarakat Wonorejo dalam kemajemukannya, banyak pengaruh pengaruh dari luar yang sangat luar biasa. Namun hal ini bisa dicegah dengan adanya kegiatan kegiatan yang dapat menyatukan. Seperti dalam setiap hari besar agama masing masing yang menjadi keamanannya adalah umat agama lain. Contoh ketika sholat idul fitri maka Linmasnya adalah Kristen atau budha, dan sebaliknya ketika acara Natalan, atau nyepi.

Sebagaiman George Ritzer mengungkapkan bahwa sistem selayaknya mampu untuk mengantisipasi pengaruh dari luar yang luar biasa. ${ }^{18}$

2. Goal Attaiment (Pencapaian Tujuan)

Tercapainya tujuan adalah harus menjadi pondasi sebuat sistem. Setiap masyarakat memiliki tujuan yang berbeda beda . ${ }^{19}$ Tapi, tidak emua tujuan tujuan individu tersebut dapat tercapai ketika dihadapkan dengan tujuan sosial yang lebih besar.

Ternyata, pada desa Wonorejo kabupaten Situbondo dapat menggapai itu meskipun problematika antar agama ini muncul pada aspek penyebaran agama. Setiap agama, terutama Islam dan Kristen sangat mementingkan masalah penyebaran agama. Karena masing-masing pemeluk merasa memiliki kewajiban untuk menyebarkannya, masing-masing yakin bahwa agamanyalah satu-satunya kebenaran yang menyangkut keselamatan di dunia dan di akhirat. ${ }^{20}$

Gambaran Kemajemukan di atas terjadi pada masyarakat Desa Wonorejo Kecamatan Banyuputih Kabupaten Situbondo. Wonorejo yang dikenal dengan Desa kebangsaan, memiliki jumlah penduduk sebanyak enam ribu orang lebih. Agama yang dianutnya terdiri dari Islam, protestan, Budha dan hindu. Tempat ibadah yang tersedia terdiri dari : Masjid sebanyak enam tempat, Gereja satu tempat,Wihara satu tempat, dan Pure satu tempat.

\footnotetext{
17 Mawardi, “Reaktualisasi Kerukunan Antar Umat Beragama”, Substantia, 17 (April 2015), 55

${ }^{18}$ George Ritzer dan Douglas J. Goodman, Teori Sosiologi Modern (Jakarta: Prenada Media, 2004), 121.

${ }^{19}$ Ritzer, Teori Sosiologi Modern, 121.

20 Syamsul Hadi, "Abdurrahman Wahid: Pemikir tentang Kerukunan Umat Beragama”, (Tesis, Universitas Muhammadiyah, Surakarta, 2015), 2
} 
Dalam kemajemukan tersebut pemerintah bersama masyarakat desa Wonorejo dapat menggapai kerukunan dan keharmonisan antar umat beraga sebagai tujuan bersama.

3. Integration (Integrasi)

Komponen - komponen yang menjadi bagian dari sitem harus diatur. Dan harus menghubungkan antara komponen yang tiga diantaranya Adaptation, Goal attainmen dan Latency. ${ }^{21}$

Antara benturan pengarus dari luar yang mengakibatkan sistem harus menyesuaikan, Tujuan bersama yang hendak dicapai yaitu kerukunan antara umat beragama dan Pemeliharaan pola yang berlangsung harus menjadi satu kesatuan yang terintegrasi satu sama lainnya dalam sebuah sistem tersebut.

4. Latency (Pemeliharaan Pola)

Selain kebersamaan dan keharmonisan dalam beragama, kehidupan sosial kebangsaan masyarakat juga integrative dan harmonis. Selama kurang lebih dua puluh tahun berlangsung desa wonorejo tercatat oleh pemerintah daerah sebagai desa yang mempertahankan dan menjunjung tinggi nilai kebangsaan dan Negara Republik Indonesia. Setiap tanggal 17 Agustus, masyarakat memperingati hari kemerdekaan dengan pelbagai kegiatan kebangsaan yang diantaranya upacara pagi harinya dan dilanjutkan dengan drama kolosal yang menampilkan sosok dan Jasa para pahlawan dalam merebut dan mempertahankan kemerdekaan republik Indonesia.

\section{KESIMPULAN}

Berangkat dari paparan diatas, dapat disimpulkan, pertama; Wujud harmoni kerukunan antara umat beragama yaitu diterapkan sebagaimana berikut: Pertama beberapa kegiatan yang dilaksanakan bersama -sama antara muslim, kristiani dan budha: seperti ritual meminta hujan, mengusir hama pertanian, bersih Desa dan larung Samudera (Peti Laut). Kedua tempat yang menjadi simbol kerukunan seperti museum Kebangsaan, makam Bhinneka, tempat-tempat Bersejarah dan home industri. Kedua; pola komunikasi umat beragama pada masyarakat desa kebangsaan Wonorejo Situbondo tercermin dalam kesehariannya. Mereka sebagaimasyarakat

${ }^{21}$ Ritzer, Teori Sosiologi Modern, 121. 


\section{Adi Susianto}

petani, guru, tokoh agama dan tokoh masyarakat dengan tanpa memperdebatkan dan mengabaikan perbedaan status keagamaannya. Namun mereka juga menjalankan ritual keagamaannya sesuai dengan agamanya. Ketiga; dalam teori Fungsionalisme Struktur, Talcott Parsons menyebutkan ada empat fungsi diantaranya Adaptation, Goal Attainment, Integration dan Latency sebagai pisau analisis dalam harmoni kerukunan umat beragama desa Kebangsaan Wonorejo Kabupaten Situbondo, diantara empat fungsi tersebut peneliti menemukan bahwa, sistem Desa Wonorejo tersebut bisa beradaptasi dengan segala pengaruh dari luar baik yang berbentuk budaya, pendidikan dan ekonomi. Kemudian tujuan bersama masyarakat Wonorejo tercapai dengan baik yaitu hidup berdampingan dengan harmonis tanpa memandang perbedaan agama. Selanjutnya Pola keberagaman tersebut sudah tercipta tidak hanya satu sampai dua tahun, namun sejak sebelum diresmikannya desa Wonorejo tahun 1905. Dan ketiga fungsi tersebut terintegrasi dengan baik dengan adanya berbagai strategi dan penyuluhan disetiap aktifitas dan dialog serta kegiatankegiatan tumpeng sewu, doa bersama di candywang dan lain sebagainya. Ditambah lagi dengan adanya penyadaran setiap kegiatan apapun tentang indahnya hidup harmoni.

\section{DAFTAR PUSTAKA}

Arikunto, Suharsimi.2002. Prosedur Penelitian: Suatu Pendekatan Praktek. Jakarta : PT Rieneka Cipta.cet-5.

Birowo, Antonious. 2004. Metode Penelitian Komunikasi: Teori \& Aplikasi. Yogyakarta: Gintanyali.

Budyatna dan Mutmainah. 1994. Komunikasi Antarpribadi. Jakarta: Universitas Terbuka.

Bungin, Burhan. 2001. Metode Penelitian Kualitatif. Jakarta: Rajawali Pers.

Cangara, Hafied.2007. Pengantar Ilmu Komunikasi .Jakarta: Raja Grafindo Persada)

Departemen Agama.2003. Konflik Etno Religius Indonesia Kontemporer. Jakarta: Litbang.

Departemen Pendidikan Nasional.2005.Kamus Besar Bahasa Indonesia.Jakarta: Balai Pustaka,

Hardiman, F. Budi. 2009. Demokrasi Deliberative: Menimbang Negara Hukum dan Ruang Publik dalam Teori Diskursus Jurgen Habermas.Yogyakarta: Kanisius. 
Irwanto.2006. Focused Group Discussion. Sebuah Pengantar Praktis .Jakarta: Yayasan Obor Indonesia.

Kriyatono, Rachmat.2007. Teknik Praktis Riset Komunikasi .Jakarta: Kencana Munir Amin, Samsul. 2009. Ilmu Dakwah. Jakarta: Amzah

Koentjaraningrat.2002. Pengantar Ilmu Antropologi. Jakarta: PT. Rieneka Cipta

Liliweri, Alo. 2003. Dasar-dasar Komunikasi Antarbudaya.Yogyakarta: Pustaka Pelajar.

Mawardi. 2015. Reaktualisasi Kerukunan Antar Umat Beragama. Substantia (Volume 17 Nomor 1, April 2015 )

Moleong, Lexy. Metode Penelitian Kualitatif, (Bandung: PT Remaja Rosdakarya, 1993).

Mulyana, Deddy dan Rakhmat, Jalaluddin.2006. Metode Penelitian Kualitatif: Paradigma Baru Ilmu Komunikasi dan Ilmu Sosial Lainnya. Bandung: Remaja Rosdakarya.

Mulyana, Deddy. 2005. Metode Penelitian Kualitatif: Paradigma Baru Ilmu Komunikasi dan Ilmu Soaial Lainnya. Bandung: PT Rosdakarya.

Nurudin.2007. Sistem Komunikasi Indonesia. Jakarta, PT Grafindo Persada

Rahmat, Jalaluddin. Metode Penenlitian Komunikasi di Lengkapi Contoh Statistik,

Respati, Djenar.2014. Sejarah Agama-agama di Indonesia Mengungkap Proses Masuk dan Perkembangannya, Yogyakarta, Penerbit : Araska.

Saidi, Ridwan.2004. Profil Orang Betawi, Asal Muasal, Kebudayaan, dan Adat Istiadat. Jakarta: PT. Gunara Kata.

Satoto, Budiono,2012. Mitologi Jawa, Jakarta: Oncor.

Tim Prima Pena. 2006. Kamus Ilmiah Populer Edisi Lengkap.Surabaya: Gitamedia Press.

Wahid, Abdurrahman.2006. Islamku, Islam Anda, Islam Kita. Jakarta:

Wijaya, Aksin. 2011. Menusantarakan Islam: Menelusuri Jejak Pergumulan Islam yang Tak Kunjung Usai di Nusantara, Yogyakarta : Nadi.

Wintala Achmad, Sri.2014. Enksiklopedia Kearifan Jawa Mengenali Mutiara Kearifan Jawa Berdasar Agung Para Pujangga, Yogyakarta: Araska. 